\title{
Thematic Analysis on COVID-19 Photojournalism in Indonesia
}

\author{
Radityo Widiatmojo $^{1, a)}$ Moch Fuad Nasvian ${ }^{2)}$ \\ ${ }^{1}$ Communication Science Departement, Universitas Muhammadiyah Malang, Indonesia \\ a) author correspondence: radityo@umm.ac.id \\ ${ }^{2}$ Communication Science Departement, Universitas Muhammadiyah Malang, Indonesia
}

DOI: https://doi.org/10.18196/jkm.11557

Article Info

Article history:

Received 22 Apr 2021

Revised 30 Apr 2021

Revised 14 Sep 2021

Revised 7 Oct 2021

Accepted 12 Oct 2021

\section{ABSTRACT}

The spread of COVID-19 in Indonesia is massive in terms of sufferers. This article aims to seek how national photo news agency ANTARA visualized the pandemic as part of contribution to COVID-19 research in the communication field. By utilizing thematic analysis and qualitative approach, the researchers want to identify, analyze, organize, describe, and report particular themes within an extensive data set of 466 photojournalism. The photos collected from www.antarafoto.com, start from 1 May until 12 May 2020. The finding shows that ANTARA visualized the current Indonesian condition of facing COVID-19 in 8 main themes, determined the countless efforts of ANTARA photojournalists working with a new protocol, and simultaneously also face the new resistance from society. The most popular theme produced by ANTARA photojournalists is economics (183 photos), Social (164), and health (80). Discussion on the most popular is divided into specific topics, namely location, subject's gender, photographic approach, image format, and news photo category. By utilizing visual ethics on the field, photojournalists communicate the symbols and reality of the real world into a frame to change people's views about COVID-19 amid the increasingly uncontrolled infodemic flow.

Keywords: Antara; COVID-19; Infodemic; Photojournalism; Thematic Analysis.

\begin{abstract}
ABSTRAK
Penyebaran COVID-19 di Indonesia terasa masif dari segi penderitanya. Artikel ini bertujuan untuk mengetahui bagaimana Kantor Berita nasional ANTARA memvisualisasikan isu pandemi ini sebagai bentuk kontribusi terhadap riset COVID-19 di bidang komunikasi. Dengan menggunakan analisis tematik dan pendekatan kualitatif, peneliti mengidentifikasi 466 foto jurnalistik, lalu menganalisis, mendeskripsikan, dan mendiskusikan ke dalam tema-tema tertentu. Sumber data berupa Foto Jurnalistik dikumpulkan dari situs www.antarafoto.com mulai 1 Mei 2020 hingga 12 Mei 2020. Hasil temuan menunjukkan bahwa ANTARA FOTO memvisualisasikan kondisi Indonesia saat ini menghadapi COVID-19 dalam 8 tema utama. Tema terpopuler yang dihasilkan jurnalis foto ANTARA adalah ekonomi (183 foto), Sosial (164 foto), dan kesehatan ( 80 foto). Pembahasan dibagi menjadi beberapa topik khusus, yaitu lokasi, jenis kelamin subjek, pendekatan fotografi, format gambar, dan kategori foto berita. Dengan memanfaatkan etika visual di lapangan, foto jurnalis mengkomunikasikan simbol dan realitas dunia nyata ke dalam bingkai untuk mengubah pandangan masyarakat tentang COVID-19 di tengah arus infodemik yang semakin tidak terkendali.
\end{abstract}

Kata Kunci: Antara; COVID-19; Infodemik; Foto Jurnalistik; Analisis Tematik. 


\section{INTRODUCTION}

An international concern-novel coronavirus disease (COVID-19) public health emergency outbreak in

Wuhan, China, on 31 December 2019, was spread to 24 countries outside China. The COVID-19 epidemic in China has triggered public mental health issues in China. The National Health Commission has issued guidelines for local authorities to promote psychological crisis response for patients, medical personnel, people undergoing medical surveillance, and civilians during the outbreak of COVID-19 (Id et al., 2020). As a result, World Health Organization declares COVID-19 as a global pandemic, which led to several campaigns to slow down its spread, such as reducing physical contact, wearing masks in public, and suggesting to hand wash more often (Bavel et al., n.d.).

In a wide range of viral outbreaks, it is impossible to predict the extent of mortality and morbidity. A newly developed pathogenic virus will be affected by viral outbreaks that may affect animals or humans without causing significant deaths; however, their psychological impacts may be severe such as panic behavior, fear, anxiety, insomnia, and hopelessness. These reactions become worse by media and social networks (Khan et al., 2020). A Twitter thread by Heidi Tworek suggests that it would be better for us to communicate COVID-19 in a more precise and fun way (Llewellyn, 2020). Communication in a Public Health crisis like in the COVID-19 case is as crucial as a medical intervention.

Indonesia is one of the last countries that admit to being infected by the novel coronavirus, and on 16 March 2020, government forces everyone to work from home. The spread of COVID-19 in Indonesia is massive in terms of sufferers the dissemination of information in the digital world. Misleading rumors and conspiracy theories of origin spread worldwide, mixed with fear-mongering, sexism, and mass purchase of face masks, both closely connected to the digital era. Not all information and news about COVID-19 are reliable; many are hoaxes and misinformation-about the outbreak; it brings the confusion generated among the public (Depoux et al.,2020).

Infodemic is a term used by social media platforms and other outlets to present the epidemic of rapidly spreading misinformation. Netizen tends to race to share new details for COVID-19, and gaining fame over social media has accelerated the spread of forged news during the current outbreak. This situation leads to massive infodemics, which may increase the risk of severe consequences for public health. The risk communication team launched a new information platform known as the WHO Information Network for Epidemics at the WHO. This platform actively reported the details relating to COVID-19 after that pandemic declared an international public health emergency (Khan et al., 2020).

The Infodemic effect of Indonesia is enormous. Research from Interface of Nava+ Group shows that Indonesian spent more time on mass media channels during COVID-19 by 56\% than before. They do chatting, texting, and messaging 53\% more (Nava, 2020). From January until 28 April 2020, 99 cases of hoaxes related to COVID-19 were handled by the police (Wahid, 2020). On 4th Mei 2020, 218 social media accounts were taken down by the police because they spread a hoax and hate speech (Yuliawati, 2020). According to the research by Senja and Panji, March, April, and May were the highest appearances of misinformation about Covid-19 in Indonesia (Yustitia \& Dwi, 2020). The misinformation also changed how the pandemic was told to others as a part of oral history (Sloan, 2020).

As countless efforts were made to develop pharmaceutical drugs to fight the new coronavirus, bewildering rumors and conspiracies hypotheses started to emerge. This misleading information also known as infodemic - escalates rapidly through social media, resulting in public panic. In extreme cases, public panic leads to distrust and a burst of racism to elements related to the outbreak's origin, China, in this case. Therefore, Chinese Restaurants, Goods from Asia, and even Chineselooking residents who have never been to China are at high risk of being victims of this viral racism (Depoux et al., 2020).

Discussing Infodemic should be dated back during the SARS and MERS outbreak, yet it becomes even more severe as the world face the outbreak of COVID-19 in 2020. It can happen mainly because the epidemic has received tremendous attention from the media and has become a global social media discussion (Huynh TL, 2020). Infodemic itself is a term used to describe the rapid spreading of misinformation (Khan et al., 2020). Cinelli adds that infodemic has forged to underline the danger of misinformation phenomena in the virus outbreak that may influence an appropriate social response (Cinelli et al., 2020). 
There are a lot of examples of infodemic during the COVID-19 pandemic. One example is a report by $\mathrm{CNN}$ about the possible loc-down of Lombardy (a region in Northern Italy) to prevent the pandemics published hours before official announcements then led to people's overcrowded public transportations to escape from Lombardy. This kind of news disrupts government efforts to contain the epidemic and possibly increases the contagion. (Cinelli et al., 2020). Another rumor concerning COVID-19 may be seen on the French Health Minister tweet several times ago. Oliver Veran's claim about Ibuprofen has been one of the most searched and shared information. Fortunately, The BBC's Reality Check team investigated and explained the story to the concerned spectators wishing to be more concerned with stories and rumors (Llewellyn, 2020).

Infodemic can be dangerous as it possibly has a negative impact. WHO Director-General, Dr. Tedros, argues that misinformation can cause confusion and spread fear. As a result, it can hamper one's response to the outbreak (Depoux et al., 2020). Khan argues that infodemic may increase the risk of mental illness. Furthermore, exposure to massive misleading information may cause mild psychological disorders such as stress to more severe problems like anxiety, insomnia, panic behavior, and hopelessness (Khan et al., 2020).

It is considered essential to understand the best way to fight the spread of misinformation. Claire Wardle argues that the fundamental way to fight misleading information is by swamping oneself with accurate information from trustworthy sources. It means that people have to ensure that the information comes from official sources rather than unclear ones (Llewellyn, 2020). Utami found that misleading information potentially creates a polarization of shared beliefs based on new forms of message artifacts (Utami, 2018). Bavel emphasizes that educating people for misinformation is needed to ensure an accurate information, a counterargument against hoaxes. That way, people are not easily exposed to false information as they know how to fact-check upon receiving it (Bavel et al., n.d.). In this case, Japelidi (Digital Literacy Activist Network), helping society by providing campaign posters within 42 local languages (Azis, 2020).

As infodemic may cause mental health problems during the COVID-19 pandemic, it is crucial to minimize it. Psychological counseling can be essential to minimize mental health risks caused by infodemic. The person prone to the illness can be asked to describe the feeling supervised by psychologists, and in some cases, the person can be asked to join cognitive behavior therapy. In more severe cases, pharmacological treatment can be prescribed to ease the mental problems. In England, socially, students and academics experience emotional disturbance (Gourlay et al., 2021). Over worrying is also reported in India due to economic losses in the entire country (Kanozia et al., 2021). Malaysia, Myanmar also indicate global stress facing COVID-19. Even Singapore as an advanced, highly urbanized city-state, faces the same problem (Wai et al., 2021). To reduce the significant impact on mental health, Ågerfalk suggests a centralized infodemic into a system information system examining the pandemic's behavioral, temporal, societal, and organizational aspects ( $⿱$ Agerfalk et al., 2020). Linda Hantrais also suggests using artificial intelligence as a primary concern for government at national and international levels (Hantrais et al., 2021), just like The COVID-19 Misinformation Challenge Digital Library designed by Jennifer Bonnet and Senta Sellers (Bonnet \& Sellers, 2019).

On the other side of infodemic, photojournalism played a role in balancing visual information. Sadia Jamil and Gifty argued that in infodemic become mentally toxic for society become the lack of media gatekeeping, and reportage journalist plays an important role to society in terms of providing the true information. (Jamil \& Appiah-Adjei, 2020). In the visual aspect, photojournalism can, indeed, be defined simply as reporting visually (Newton, 2013). It is a practice in which a reporter communicates stories using still and moving images rather than describing them through plain text (Greenwood, 2019). Despite its simple definition, photojournalism requires complex tasks as the photojournalist has to contextualize any moment, from the most straightforward thing like a person's smile to the most complicated one such as war. In other words, a photojournalist who wants to capture photos has to have the ability to catch "the decisive moment," which are described by Henri CartierBrenson (1952) as a moment where the visual, as well as the psychological elements of the objects, come together in perfect harmony (Newton, 2013).

Photojournalism is undoubtedly not a current practice as it was believed to date back hundreds of years ago. Cliff Edom (1976), a photojournalism educator, argued that cave art could be considered a visual report. Illuminated Egyptian manuscripts were also a part of the "illustrated press," and even fine arts could be acknowledged as visual reports since they sometimes describe important events (Newton, 2013). 
Although the practice has been available for many years, people used photojournalism around the mid-twentieth century when photography was invented. Society demanded more realistic-looking images because drawings and paintings were lack of accuracies and detailed. This situation led to an experiment to foster a mechanical process that could capture images precisely the same as in real life. As a result, a public announcement was made in 1839 describing two processes for capturing a photographic image called the Daguerreotype by Louis Jacques Mandé Daguerre. William Henry Fox Talbot continued the innovation by introducing another mechanism process named The Talbotype that used paper to create a negative image with more minor detail but later could be used to produce multiple positive versions of the portrait. Indeed, The Talbotype is the foundation of photojournalism until it slowly replaced by digital technology in the late twentieth century (Greenwood, 2019).

The development of technology has led photojournalism to a new era where journalists must be able to make fantastic imagery create a story. The photographer has to be able to combine lavish still and moving images with appealing text and high-quality sound if needed (Newton, 2013). It means that a photojournalist who masters the skill of capturing photos, writing stories, shooting videos, and editing content will have more advantages at surviving. Above all of it, photojournalists have a great responsibility to the reader to provide a visual message (Wijaya, 2014).

As talking about the astonishing development of technology, photojournalism remains one of the best ways to convey messages. Photojournalism can be a crucial thing to reduce the distance between audiences and events. It means that photojournalism can fill the gap among audiences so that they can still follow geographically far apart events without actually having to be there. Furthermore, photojournalism can make spectators more aware of the important world events by giving realistic images (Pogliano, 2015).

Pink stated that the existence of visual data along with the text gives the spectator many possibilities. The visual image can make the viewer's engage with the experiences of the people that were captured. Indeed, it can grow their empathetic level towards a particular event (Heng, 2011). Laura Marks also stated that photographs give strong evidence of something. They describe a point of view, editorial judgment, the object photographed, and even the imagination of the image-makers (Newton, 2013).

Interestingly, using photographs as evidence is regarded as a convention rather than a guarantee of truth. Photographs are understandable because they do not provide absolute proof, although they are captured in the most realistic styles. The realism of photography can mean that it is as good as the actual object, yet for some people, the realism of the photography is fake or artificially made from beginning to end. Barthes then strengthens this argument, that the authenticity of the photographs does not lie on the picture itself, but on the part of the editors and then of the spectators who accept the text's claim (Taylor, 2000).

On the one hand, Photojournalism and its practices have caught scholars' attention, leading to several unique research types. A study by Stuart Allan pinpoints the relation between photojournalism and Citizen Journalism. The result shows little citizen journalism presented in a situation involving a story of a significant impact in the local community (Allan, 2015). Another article by Keith Greenwood reveals the complex relationship between photojournalism and photojournalism in various aspects of technical and real life. He also pointed that research on photojournalism is not as much as mass communication research (Greenwood, 2019). On the other hand, the methods of analysis photojournalism as a communication text are various and have different approaches. Semiotic is one the most useful approaches to defining and seeking the dialectic between a photograph's connotative and denotative meaning. Rachmawati uses semiotic to seek the symbolic meaning of Putu Sayoga's image covering Tsunami and Earthquick of Palu. The result shows that Sayoga uses religious and cultural symbols to capture the spirit of Palu's society facing the disaster (Rachmawati, 2020). Content analysis also demonstrates the various technique of analyzing photojournalism. Research on visual literacy also shows how visual hoaxes operate by manipulating several image dimensions such as caption and context (Widiatmojo, 2020). These various research shows that photojournalism plays a vital role to combat infodemic.

As people's demand for online sources increases, media are trying to provide information that can trigger reader interest. The information itself may vary, from the COVID-19 map to the change of lifestyle during the pandemic. Among the media presenting visual news on COVID-19, ANTARA FOTO catches the researcher's attention because it offers. As a National Photo News Agency of Indonesia, researchers want to describe how do ANTARA FOTO visualized this issue in a particular theme. The urgency of this research is to present how the visualization of Covid-19 in Indonesia. 
METHODS

This thematic analysis uses a qualitative approach to get a depth overview from visual data of 466 photojournalism from the website of www.antarafoto.com, from 1 May until 12 May 2020. The dataset was built during the data coding process. The first process in building and the coding dataset is to understand the data itself (Heriyanto, 2019). Furthermore, all photos are classified into one central theme.

The following process is classifying each photo into a cluster that has been determined by researchers, namely the location of the photo, the gender of the subject of the photo, photographic approach, image format, angle of shooting, and type of news. Here is the dataset created by the researchers:

Table 1. Thematic Analysis Dataset

\begin{tabular}{llllcccc}
\hline No & Photos & $\begin{array}{c}\text { Title } \\
\text { and } \\
\text { Caption }\end{array}$ & Theme & Location & $\begin{array}{c}\text { Subject's } \\
\text { Gender }\end{array}$ & $\begin{array}{c}\text { Photographic } \\
\text { Approach }\end{array}$ & $\begin{array}{c}\text { Angle } \\
\text { Photo } \\
\text { Category }\end{array}$ \\
\hline 1 & & & & & \\
$\ldots$ & & & & & \\
466 & & & & & \\
\hline
\end{tabular}

The next step is presenting the data, which it should be coherent, logical, and not repetitive (Nowell et al., 2017). To that end, researchers conducted in-depth interviews with an Independent Editor and ANTARA FOTO photojournalists. Utilizing particular purposes, researchers chose two ANTARA photojournalists, namely Aribowo Sucipto and Budi Candra. The practical and logical reason for choosing Aribowo was because he has been working as an ANTARA photojournalist for more than 15 years. Meanwhile, Budi Candra represented a millennial photojournalist with eight years of experience. To enrich the discussion, researchers conducted an interview session with Okky Ardya, because she is actively involved in developing photography education in Indonesia and her internationally recognized works. Okky himself is an editor, writer, and translator with international experience.

\section{RESULT AND DISCUSSION}

A large dataset was established to seek a photojournalism theme on COVID-19. By coding 466 photographs from 1 May until 12 May 2020, the finding shows there are eight issues as shown below:

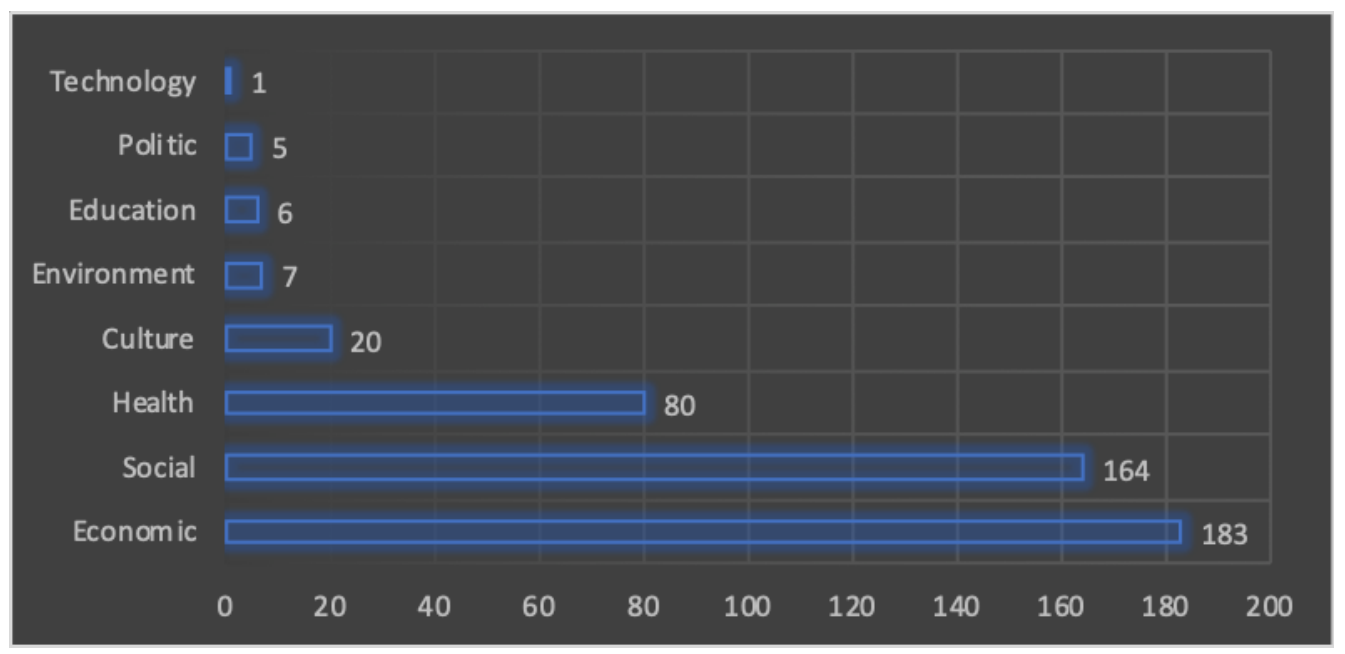

Figure 1. Various Theme 
Generally speaking, the graphic above shows that economic and social issues are the most covered issues, and health also cultural issues. Meanwhile, the environment, education, politic, and technology are less covered.

Although COVID-19 impacts all aspects of human life, the photojournalist of ANTARA seems to highlight economic, social, and health issues. One example is a photo by Mohammad Hamzah, who visualizes pillow artisans who sell their products to Kalukubula Village, Sigi Regency, Central Sulawesi. The photo caption tells that the community cannot be instructed to stay at home because they have to work to earn money for their daily needs. On social issues, a photo by Raisan Al Farisi presents how volunteers from Bandung dressed as robots in costumes around the village to tell the people to stay at home instead of hanging out. For health issues, Fachrurrozi recorded how medical workers and the community carried out the funeral procession of COVID-19 victims in Tarakan, North Kalimantan. These three examples illustrate how the visualization of the three main issues carried by ANTARA photojournalists.

Infodemic also operates in health, social and economic themes. This happened because of the public's ignorance of correct information. The type of Indonesian society that is collectivist and loves to share on social media makes misinformation on health, social and economic themes consumed as truth. Thus, the publication of photojournalism on social, economic, and health themes is an effort of ANTARA FOTO to counterbalance misinformation in the community.

These three themes, the researchers refined into a more extensive coding dataset, namely aspects of location, the gender of photographers, gender of subject photos, photographic approaches, types of news, and technical aspects.

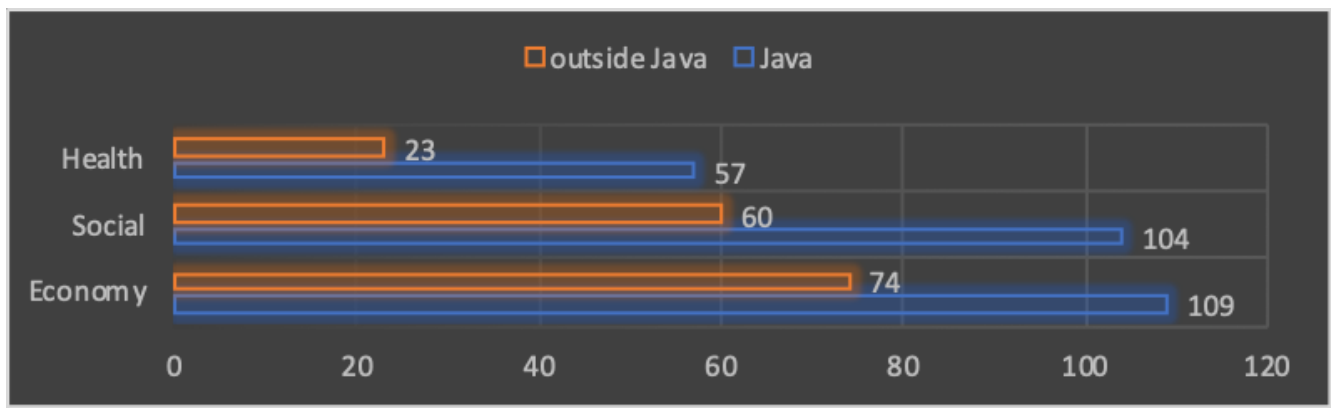

Figure 2. Location of the Photos

The island of Java has a more significant portion of photo locations and reporting than the other place of Indonesia, in economic, social, and health issues. This data shows that ANTARA prioritizes the visualization of the current Indonesian condition of facing COVID-19 originating from Java, considering that the island with six provinces is the most severely affected area in Indonesia.

As the most populous island, Java has a variety of visualization of the economy, ranging from the sluggish traditional markets, malls, various types of MSMEs, agricultural commodities, transportation, terminals, airports, hospitals, health posts, social assistance, or social restriction activities. With an abundance of material in the economic, social, and health fields, photographers are freer to do visual exploration on the island of Java compared to other islands outside Java. The dominance of the island of Java also shows that the economy is still concentrated on this island. Socially, the island of Java is the first destination island of migrants from other places in Indonesia, so that issues around humanity are far more numerous and more accessible to find than outside Java. Likewise, with health issues. The number of hospitals referenced COVID-19, medical activities, medical devices makes photo reporters much more flexible in determining visualization of COVID19.

However, visualization of the current Indonesian condition of facing COVID-19 in various regions shows that photojournalists continue to work optimally at the forefront of this pandemic. Photographer jobs are jobs that require working in the field. This work is unique because it drains two forces at once, namely physical and mental. So, male photojournalists do dominate. Research data shows that of the 466 photographs, $91.4 \%$ were the results of shots from male photographers, while $8.6 \%$ or 40 photos were the work of 7 female photographers. 
Regarding gender, the researcher also mapped the current Indonesian condition of facing COVID19 visualization pattern based on the gender of the photographic subject on economic, social, and health issues, as in the following figure.

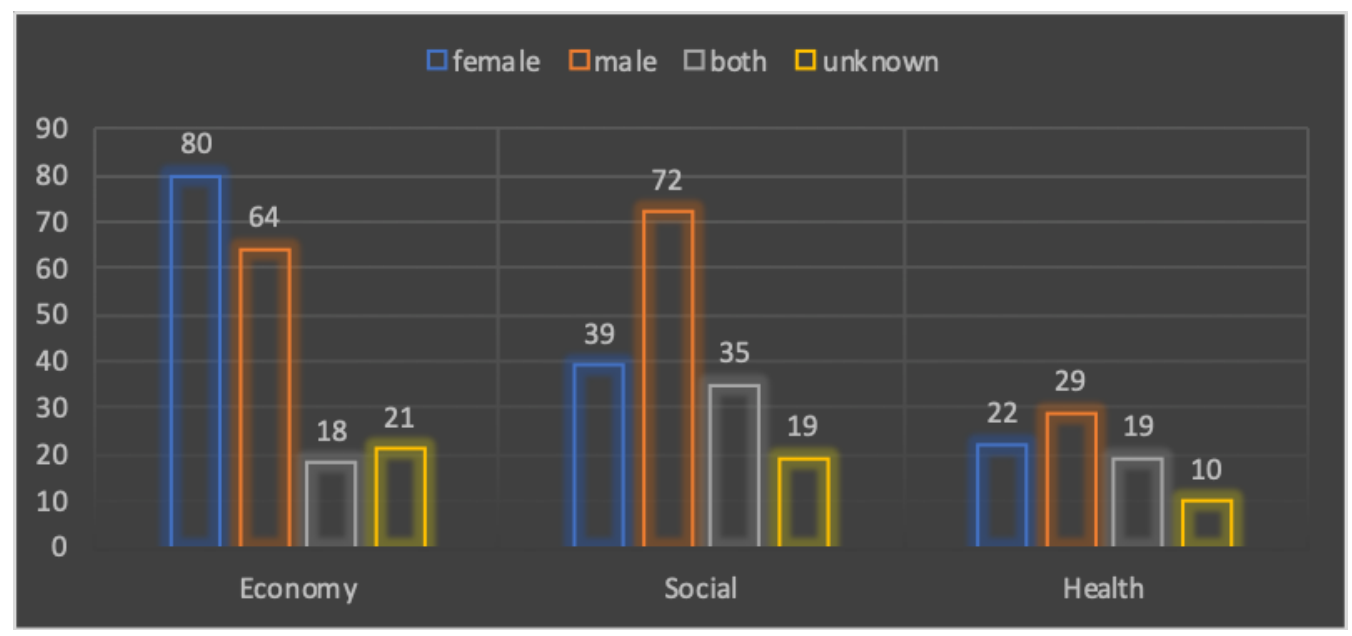

Figure 3. Subject's Gender in Photos

On economic issues, the visualization of women as photo subjects occupies the highest position, followed by men and both genders in a photo. Whereas on social and health issues, men are more visualized than women. This data also shows that journalistic photographs do not show humans, so no gender identification is entered.

From an infodemic perspective, misinformation will hit anyone who has access to the source. The presentation of men and women in journalistic photos can be seen as a humanist effort to report the incidence of Covid-19 using a gender approach.

This data represents women as economic $\operatorname{cogs}$, along with men. Various visualizations of women in economic activities show that the role of women as equal to men. There is a photo by Prasetia Fauzani showing a mother making traditional Madumongso food in Kediri. Another photo by Ahmad Subaidi that photographs a woman wearing a mask carrying a banana in Mataram. The tendency of ANTARA to show 80 photos of women as subjects on economic issues cannot be seen from a patriarchal cultural perspective because data shows that ANTARA also displays 64 photos with men as subjects.

The subject selection of gender is naturally not thought of by photographers. Coverage on the location did not see gender as a calculated aspect. As ANTARA photojournalist Banyuwangi bureau, Budi Candra stated that the gender in the frame was part of the visualization of the issue that was about to be covered. There is absolutely no intention to distinguish gender. In terms of the tendency of women to appear in economic themes, Budi Candra added that the reality on the field explained the reality. Indeed, because there was no manipulation, it depends on how the photographer approached the subject. For Budi Candra, a photographic approach, be it portrait or candid or snapshot, dramatically influences the message.

Research data shows that the majority of ANTARA photojournalists use the snapshot approach to the visualized economic, social, and health issues, as seen in the following figure. 


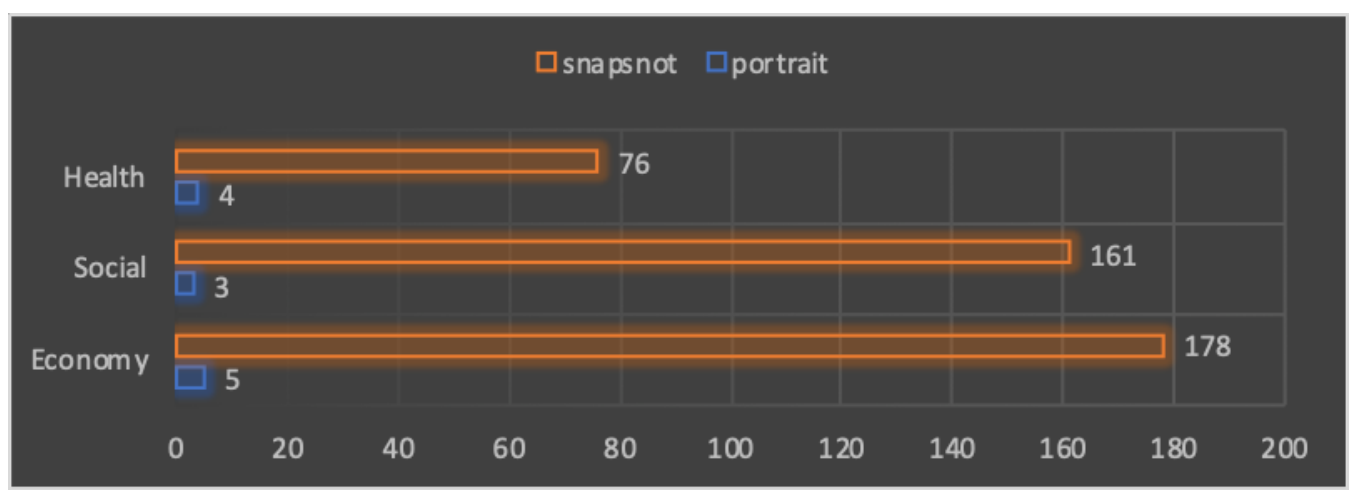

Only $2.6 \%$ or 12 of 466 photos were visualized on the three main issues using the portrait approach. ANTARA photojournalists focus on a snapshot approach that does not require a personal approach to a particular photo subject. People's daily activities are the dominant photos from the economic issue. Oky Lukmansyah visualizes the activities of women batik wearing masks. Ampelsa shows a photo of a crowd of people buying cheap food held by the Aceh City Government. Ari Bowo Sucipto visualizes pastry sellers who organize their wares in a bread factory in Malang. People's daily activities also dominate the photos of social issue. Harvian Perdana recorded a high school teenager wearing a crossed-out uniform (a sign of graduation festivity), a convoy in the middle of Batang, Central Java. Fikri Yusuf photographed the reception of aid from lecturers to COVID-19 impacted students in Bali. While on the theme of health, visualization is dominated by health protocol activities. Like the test drive-thru swab by Indrianto Eko at Pertamina Jaya Hospital, Jakarta, and another photo is by Fachri visualized medical staff spraying disinfectants in Bekasi.

As the visualization with a portrait shooting approach is very rarely made, this data reflects two things. First, most of ANTARA photojournalists prefer to cover an event rather than recording the emotions on the faces of humans. Portrait photos require exceptional interpersonal communication. Excellent communication will lead to solid portrait visualization because the subject feels comfortable and has confidence in the photo reporter. From the editor's point of view, like Okky Ardya, this process takes a long time not to do other reporting activities. Aribowo Sucipto, an ANTARA photojournalist, stated that portrait photos would be taken if the issue was compelling. Difficulty to get portrait photos when the COVID-19 pandemic is realized because there are fears of contracting despite using personal protective equipment (PPE) when photographing. In this issue, not everyone wants to be photographed with a portrait approach. That is the condition on the ground. Therefore Aribowo prefers to do coverage.

Second, in business, portrait photos are not very popular in the Indonesian media. If the demand for portrait photos is rare, then there is a possibility that portrait photos will not sell well in Indonesian media. Budi Candra stated that he once took a portrait approach but did not sell well. While from the perspective of an Editor, Okky Ardya focuses more on the potential of a photo related to news values. If in Jakarta or other capital cities, it is possible to get news values in public figures. In contrast, there are no strong elements in public figures outside of the Indonesian capital city, so it is not possible to take portraits with weak news values. Moreover, Budi Candra also realized this.

The other side of this data shows that the portrait is identical to the photo story assigned by ANTARA to a photojournalist. Aribowo and Budi Candra both stated this. When the market does not want a portrait photo, photojournalists outside of the Indonesian capital city are still determined to produce a portrait photo even though the photo is powerful visually.

When infodemic spread massively, society needs to see the factual reality. The data that shows that covering covid-19 by photographing the actual moment proves that Indonesian still believe in what they see and are not constructed just like portrait photos.

In addition to the approach to the subject, the technical approach also produces quite exciting findings, as shown in the following figure. 


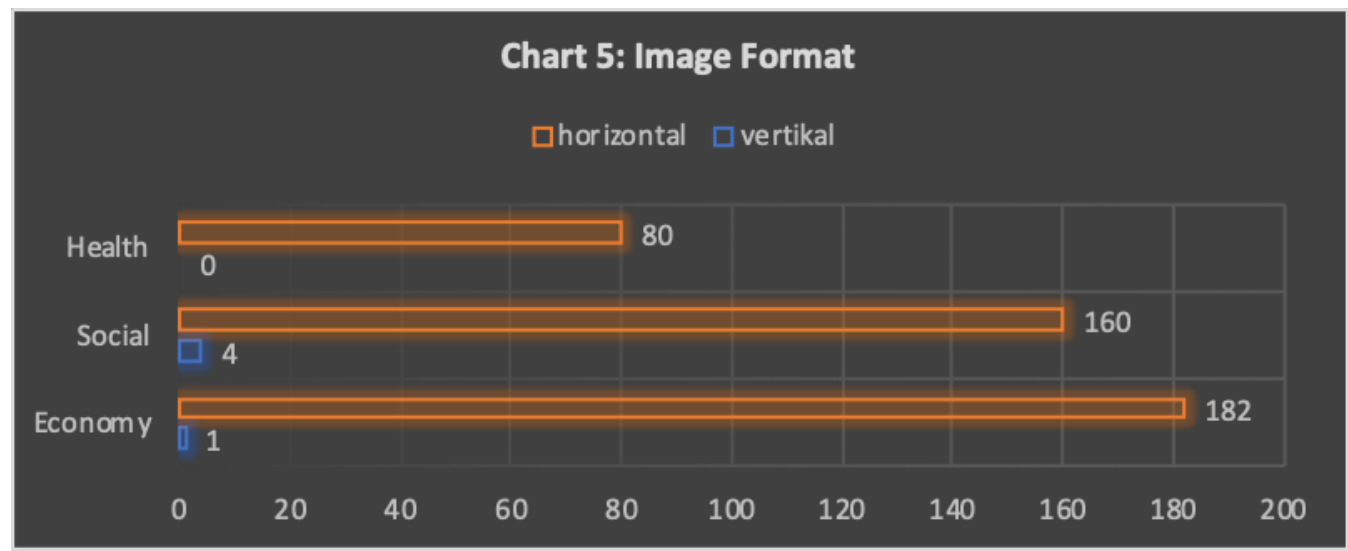

Figure 5. Image Format

This data shows the superiority of horizontal photos format. One common cause of horizontal format photos is the desire of the client. Horizontal format photos are very flexible in terms of layout and editing, making it easier for clients. Apart from that, the client directly contacted Aribowo to produce photos in a horizontal format. At the same time, the vertical format is not so flexible and does not make entire spatial space on the website. Budi Candra and Aribowo always send photos in horizontal and vertical formats, but most published ones are horizontal.

Apart from the layout and business aspects, this data reflects how humans see this world. In 2008, National Geographic photographer John Stanmeyer once told researchers that humans see the world horizontally. At a certain point, how human see the world become psycho-cultural knowledge (Ajidarma, 2016). His habit is a factor that why photojournalists tend to visualize an issue in a horizontal format. Another habit related to the way of seeing is when dialoguing. Interaction between humans makes us look into each other's eyes. This habit also affects the shooting angle, as seen in the following figure.

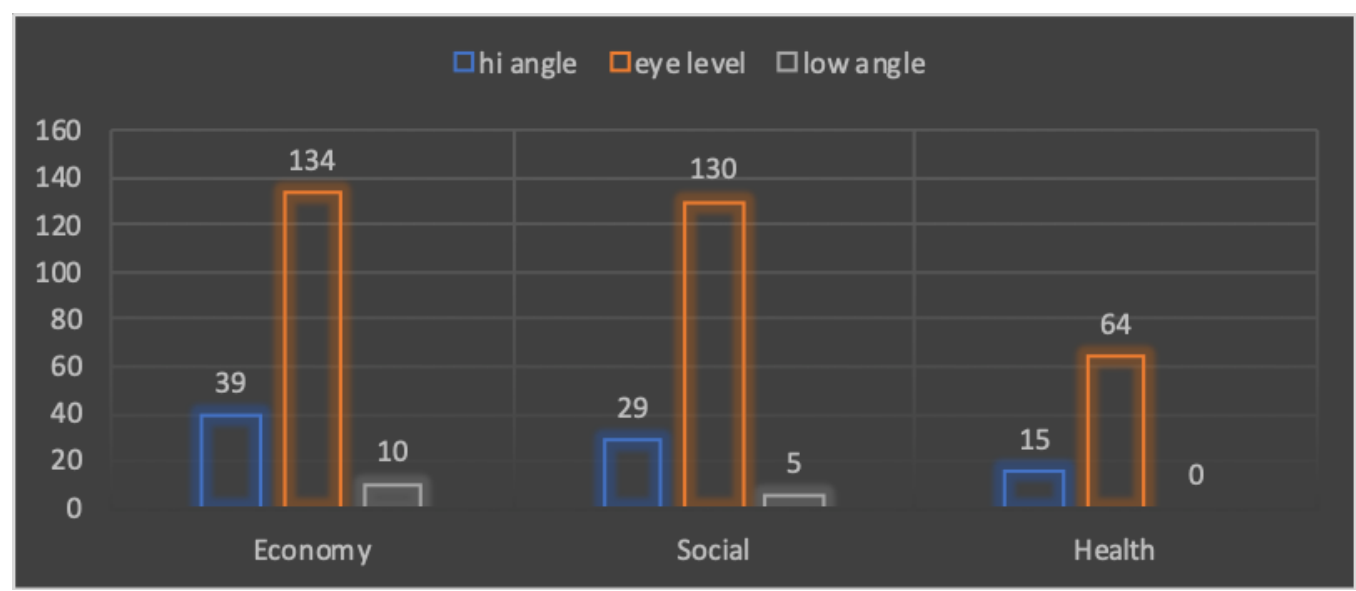

Figure 6. Various Photographic Angle

This data shows that the three main themes are visualized with eye-level angles. Visually, the eyelevel places the camera in line with the subject's eyes so that the viewer is invited to appear as if he was standing in the middle of a visualized situation. Like a photo by Budi Candra, for example, he photographed the Cash Social Aid (bantuan sosial tunai) officer interacting with the Banyuwangi community. In the photo, the viewer seems to be near the officer. There is a sense of closeness when using eye-level angles, unlike the low-angle and hi-angle, which tends to explore visual creativity. Radmad's work with a low-angle shows how fishers in Aceh dry anchovy. Retrieval from an unusual angle will cause creative visual attention. At the same time, hi-angle is used to show the breadth, such as the work of Aloysius Jarot, which shows the quiet of the Boyolali-Solo toll road. The photo was taken from the crossing bridge above the toll road. 
Aribowo stated that photojournalists are always required to produce photographs from various angles for the presentation. Thus, when sending photos to the agency, at least, the minimum deposit has five different angle variations. The editor's taste also affects whether or not a photo rises on the website page between the photos. Angle variations, according to Aribowo, have an impact on the decision of photojournalists to produce a variety of news, be it features, spot news, or photo stories.

The following graph shows the trends in the photo news category displayed during the COVID-19 issue.

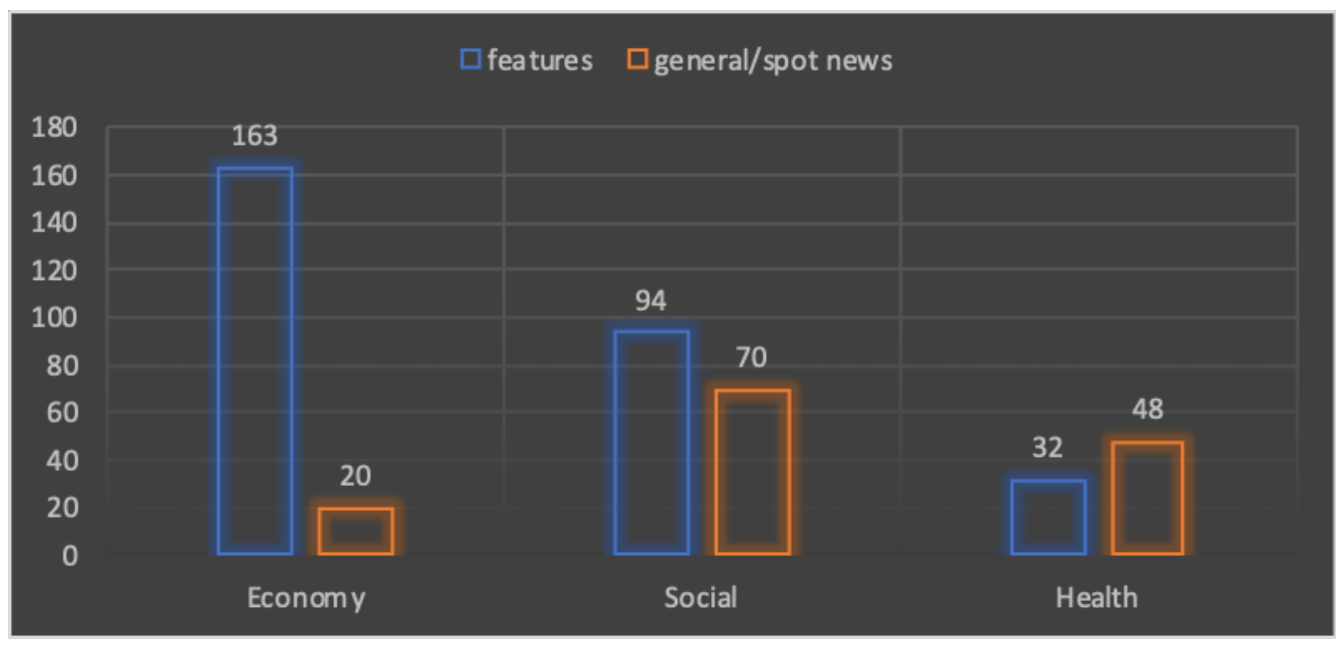

Figure 7. Photo News Category

On the one hand, the data above shows that health themes are more dominated by general photos or spot news. This data happens because the average news related to health is already scheduled. Like the work of Muhammad Iqbal, for example, he photographed officers and police who were spraying on the streets of the city of South Tangerang using a gunner sprayer. Another photo was from scheduled rapid test examinations, such as Destian's work showing officers who will inspect cigarette factory workers in Tulungagung.

On the other hand, features become the most dominant type of news on economic and social issues. Aribowo stated that COVID-19 is a part of human history, both in Indonesia and throughout the world. The photojournalist who reports on the COVID-19 issue is also part of history. Furthermore, the best way to freeze history is to present it through timeless feature stories. Like the photo by Raisan Al Farisi, an officer was wearing blue robotic clothes going around the village to urge residents not to gather. The robotic outfit will become a part of history in Bandung. The robotic costume will be a symbol and sign that the citizens of Bandung have uniquely fought against COVID19. Likewise, Rivan Awal's photo visualized a Balinese dance teacher teaching online in front of his laptop. Online teaching will become part of human history. Photo features show the sides of humanism that can be enjoyed and remembered throughout the year. Essentially, features is just a memory trace of a time, in short, the imaginary future (Svarajati, 2013).

The power of photo features is what drives Aribowo and Budi Candra to make interesting feature works. Although sometimes they want to be free from the COVID-19 issue, Budi Candra is aware that on location, everyone is affected by COVID-19, and it is impossible not to show the humanist side of a pandemic.

What can we learn from the result above? A good photograph is a photo that tells a story, about a moment, about life. In the end, it is just about humans (Sumaku, 2016). In a photo, people become history. In the hand of photojournalists, some of the great world histories was frozen very well.

As a part of visual communication, photojournalism has shown a great part of visual ethics in the digital era. Visual ethics refers to how images affect how we think, feel, behave, and interpret the meaning for good matters (Newton, 2005). Photojournalists use visual ethics as a part of their job in the field. It starts with how they choose the photography subject, the location, what theme they will produce, and how the visual approach is to produce high-quality photojournalism. The truth of information carried within the photojournalism potentially changes people's views about COVID-19 amid the increasingly uncontrolled infodemic flow. As Brian Kennedy states that $90 \%$ of information 
was absorbed by human eyes (Newton, 2005), photojournalism operates by communicating symbols and reality of the real world into a frame that makes it more understandable and shareable.

A photojournalist is one of the front guards in this pandemic. They have done a very noble job, just like doctors and nurses. Photographers have to struggle every day to provide accurate information to the public. The eight themes generated during the pandemic illustrate high totality and professionalism work in visual reporting.

COVID-19 forced the situation to change completely, mainly related to health. Thus, ANTARA FOTO issued a pretty good policy in terms of protecting photo reporters from COVID-19 risk. Provision of Personal Protective Equipment or PPE, delivery of hand sanitizers, and masks that are carried out regularly. The Bureau Chief ANTARA FOTO recommendations are also crucial for colleagues in the field. They include not needing too much force to get the best photos, avoiding the hospital, avoiding the burial of COVID-19 patients, and using telephoto lenses, and not even needing to work the whole week. Moreover, the photojournalist suggested taking care of themself and resting a lot at home.

Aribowo and Budi Candra support the existence of this policy. Safety is number one in the middle of this pandemic. Besides, new habits also appear to shift old habits. Before the pandemic, photojournalists usually gathered in one location to just chat and discuss, then now it does not happen again. After they were covering an issue, they had to go straight home. They should not take much time in the location. Aribowo admitted that he kept the distance from others on the field, even though he already knew them. Even though they already use PPE or a military role, he keeps his distance and even moves away when approached by others.

Changes also occur with people who want to be photographed by photojournalists. There is resistance from photo subjects in the field. There was a new kind of fear when the photojournalist pointed the camera at him. Therefore, it takes patience to a high degree when dealing with people who are resistant to photojournalists. It is this vigilant attitude that will become the new norms.

\section{CONCLUSION}

The thematic analysis shows eight central themes that ANTARA FOTO visualized the current Indonesian condition of facing COVID-19. The most popular theme is Economic (183 photos), followed by social (164), Health (80), culture (20), environment (7), education (6), politics (5), and technology (1). Analysis of the three most popular themes is as follows. First, Java is the most visualized location. Next, women, as the gender subject on the economy theme make the highest appearance. Third, reportage by a snapshot is the dominant photographic approach. Then, the majority of photos are shown within a horizontal format. Fifth, the angle of the photograph is dominated by an eye-level angle. The last features are the most popular kind of news that appears on the ANTARA FOTO website. On the one hand, the richness of thematic issues in May 2020 illustrated how ANTARA FOTO battled the rise of infodemic in March, April, and May in Indonesia. On the other hand, those varieties of themes demonstrate the decent work of ANTARA FOTO photojournalists in the field that work with new protocols and face new resistance from society. Moreover, by utilizing visual ethics on field, photojournalist communicating symbols and reality of the real world into a frame to change people's views about COVID-19, amid the increasingly uncontrolled infodemic flow. As pilot research on photojournalism using thematic analysis may have a distinct lack of building a dataset and the analysis process. Suggestions are encouraged to understand the nature of the photo itself and generate a dataset based on the character of particular photos.

\section{ACKNOWLEDGMENT}

We would like to send our sincere gratitude to Universitas Muhammadiyah Malang, Communication Science Department, and ANTARA FOTO that support this research. Also, to Okky Ardya, Aribowo Sucipto, and Budi Candra, for the enlightened discussion. 


\section{REFERENCES}

Ågerfalk, P. J., Conboy, K., \& Myers, M. D. (2020). Information systems in the age of pandemics: COVID-19 and beyond. European Journal of Information Systems, 29(3), 203-207. https://doi.org/10.1080/0960085X.2020.1771968

Ajidarma, S. G. (2016). Kisah Mata - Fotografi antara Dua Subjek: Perbincangan tentang Ada. Galang Press.

Allan, S. (2015). Introduction: Photojournalism and citizen journalism. Journalism Practice, 9(4), 455-464. https://doi.org/10.1080/17512786.2015.1030131

Bavel, J. J. Van, Baicker, K., Boggio, P. S., Capraro, V., Cichocka, A., Cikara, M., Crockett, M. J., Crum, A. J., Douglas, K. M., Druckman, J. N., Drury, J., Dube, O., Ellemers, N., Finkel, E. J., Fowler, J. H., Gelfand, M., Han, S., Haslam, S. A., Jetten, J., ... Weeden, K. A. (n.d.). COVID-19 pandemic response. Nature Human Behaviour. https://doi.org/10.1038/s41562$\underline{020-0884-\mathrm{Z}}$

Bonnet, J. L., \& Sellers, S. (2019). The COVID-19 Misinformation Challenge: An Asynchronous Approach to Information Literacy. Internet Reference Services Quarterly, 24(1-2), 1-8. https://doi.org/10.1080/10875301.2020.1861161

Cinelli, M., Quattrociocchi, W., Galeazzi, A., Valensise, C. M., Brugnoli, E., Schmidt, A. L., Zola, P., Zollo, F., \& Scala, A. (2020). The COVID-19 Social Media Infodemic. 1-18.

Depoux et al., 2020. (2020). The pandemic of social media panic travels faster than the COVID-19 outbreak. 400.

Gourlay, L., Littlejohn, A., Oliver, M., \& Potter, J. (2021). Lockdown literacies and semiotic assemblages: academic boundary work in the Covid-19 crisis. Learning, Media and Technology, 1-13. https://doi.org/10.1080/17439884.2021.1900242

Greenwood, K. (2019). Photojournalism and Photojournalists. The International Encyclopedia of Journalism Studies. https://doi.org/10.1002/9781118841570.iejs0278

Hantrais, L., Allin, P., Kritikos, M., Sogomonjan, M., Anand, P. B., Livingstone, S., Williams, M., \& Innes, M. (2021). Covid-19 and the digital revolution. Contemporary Social Science, 16(2), 256-270. https://doi.org/10.1080/21582041.2020.1833234

Heng, T. (2011). Recent methodological opportunities in online hypermedia - a case study of photojournalism in Singapore. Sociological Research Online, 16(2). https://doi.org/10.5153/sro.2381

Heriyanto. (2019). Thematic Analysis sebagai Metode Menganalisa Data untuk Penelitian Kualitatif. May. https://doi.org/10.14710/anuva.2.3.317-324

Huynh TL. (2020). The COVID-19 risk perception: A survey on socioeconomics and media attention. Economics Bulletin. . AccessEcon, 40(1(1), 758-764.

Id, J. G., Zheng, P., Jia, Y., Chen, H., Mao, Y., Chen, S., Wang, Y., Fu, H., \& Dai, J. (2020). Mental health problems and social media exposure during COVID-19 outbreak. December 2019, 110. https://doi.org/10.1371/journal.pone.0231924

Jamil, S., \& Appiah-Adjei, G. (2020). Battling with infodemic and disinfodemic: the quandary of journalists to report on COVID-19 pandemic in Pakistan. Media Asia, 47(3-4), 88-109. https://doi.org/10.1080/01296612.2020.1853393

Kanozia, R., Kaur, S., \& Arya, R. (2021). Infodemic during the COVID-19 lockdown in India. Media Asia, 48(1), 58-66. https://doi.org/10.1080/01296612.2021.1881286

Khan, S., Siddique, R., Li, H., Ali, A., Adnan, M., Bashir, N., \& Xue, M. (2020). Impact of coronavirus outbreak on psychological health. 10(1), 1-6. https://doi.org/10.7189/jogh.10.010331

Llewellyn, S. (2020). Covid-19: how to be careful with trust and expertise. 1160(March), 1-2. https://doi.org/10.1136/bmj.m1160

Newton, J. H. (2005). Visual Ethics Theory. In K. Smith, S. Moriarty, G. Barbatsis, \& K. Kenny (Eds.), Handbook of Visual Communication, Theory, Method and Media. Lawrence Erlbaum Associates.

Newton, J. H. (2013). Photojournalism. https://doi.org/10.1002/9781405186407.wbiecp035.pub2

Nowell, L. S., Norris, J. M., White, D. E., \& Moules, N. J. (2017). Thematic Analysis: Striving to Meet the Trustworthiness Criteria. 16, 1-13. https://doi.org/10.1177/1609406917733847 
Pogliano, A. (2015). Evaluating news photographs: Trust, impact and consumer culture in the digital age. Journalism Practice, 9(4), 552-567. https://doi.org/10.1080/17512786.2015.1030141

Rachmawati, A. (2020). Semiotika Foto Bencana Karya Putu Sayoga. FOMO, 01, 12-29. http://student-research.umm.ac.id/index.php/FOMO/article/view/8051

Sloan, S. M. (2020). Behind the 'Curve': COVID-19, Infodemic, and Oral History. The Oral History Review, 47(2), 193-202. https://doi.org/10.1080/00940798.2020.1798256

Svarajati, T. (2013). Photagogos: Gelap Terang Fotografi Indonesia. Suka Buku.

Taylor, J. (2000). Problems in Photojournalism: realism, the nature of news and the humanitarian narrative. Journalism Studies, 1(1), 129-143. https://doi.org/10.1080/146167000361212

Utami, P. (2018). Hoax in Modern Politics: The Meaning of Hoax in Indonesian Politics and Democracy. JURNAL ILMU SOSIAL DAN ILMU POLITIK (Jsp), 22(2), 85-97. https://doi.org/10.22146/jsp.34614

Wai, K. S., Khine, W. Y. K., Lim, J. M., Neo, P. H. M., Tan, R. K. J., \& Ong, S. E. (2021). Malaysia, Myanmar and Singapore: common threads, divergences, and lessons learned in responding to the COVID-19 pandemic. The Round Table, 110(1), 84-98. https://doi.org/10.1080/00358533.2021.1875693

Widiatmojo, R. (2020). Literasi Visual sebagai penangkal Foto Hoax Covid-19. SOSPOL, 6(1), 114127. http://ejournal.umm.ac.id/index.php/sospol/article/view/11221

Wijaya, T. (2014). Foto Jurnalistik. Gramedia.

Yustitia, S., \& Dwi, A. P. (2020). An Analysis on COVID-19 Disinformation Triangle in Indonesia. Jurnal Komunikator, 12(2), 116-128. https://doi.org/https://doi.org/10.18196/jkm.122040 